\title{
MEDIAÇÃO DOCENTE ONLINE PARA COLABORAÇÃO: NOTAS DE UMA PESQUISA-FORMAÇÃO NA CIBERCULTURA
}

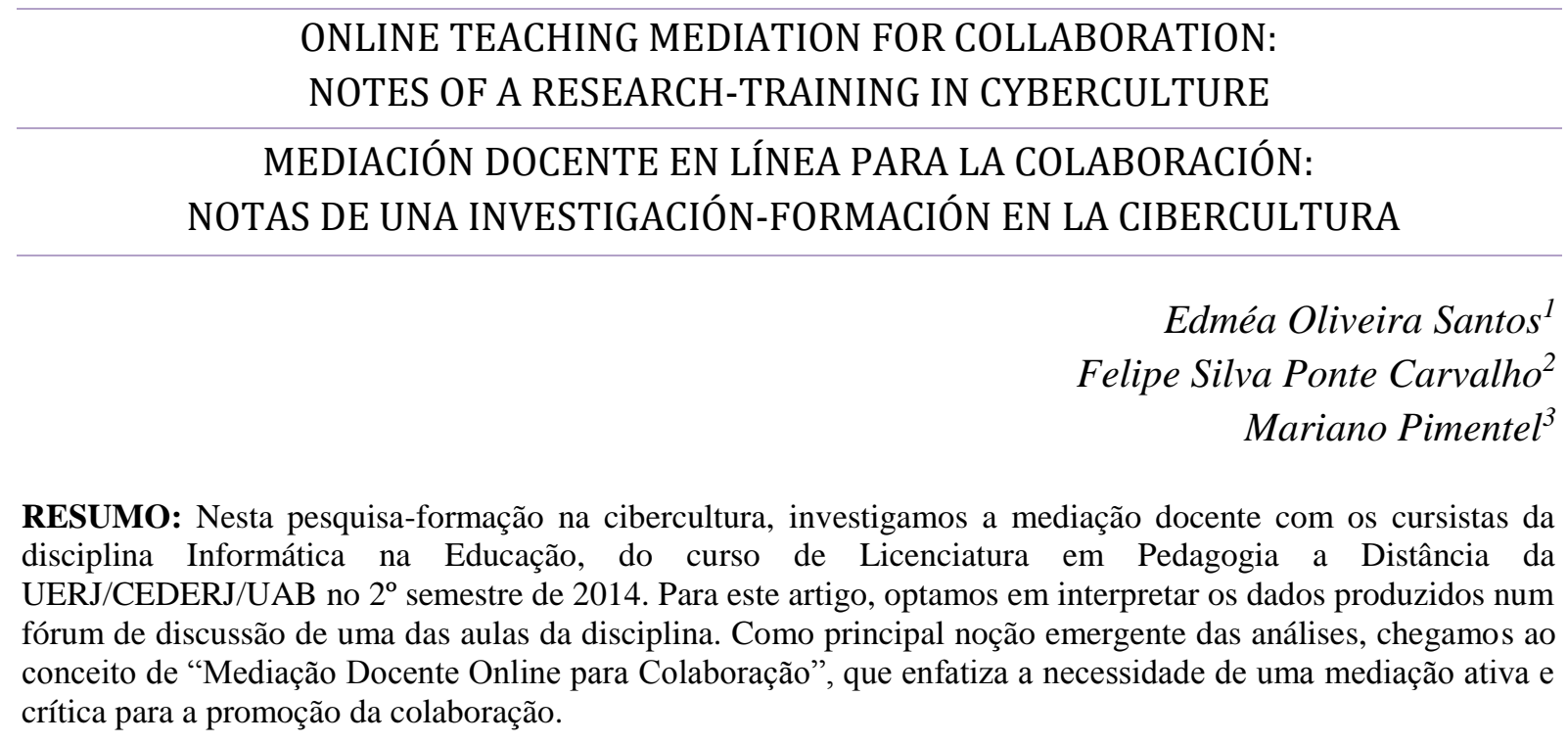

PALAVRAS-CHAVE: Mediação docente online. Colaboração. Pesquisa-formação na cibercultura.

ABSTRACT: In this research-training in cyberculture, we investigate the teaching mediation with the students of the discipline of "Informatics in Education", on the Licentiate Degree in Distance Pedagogy from the UERJ/CEDERJ/UAB in the 2nd half of 2014. For this paper, we chose to interpret the data produced in a discussion forum in one of the discipline classes. As the principal emerging notion from the analyses, we arrive at the concept of "Online Teaching Mediation for Collaboration", which emphasizes the need for an active and critical mediation for promoting collaboration.

KEYWORDS: Online Teaching Mediation. Collaboration. Research-training in cyberculture.

RESUMEN: En esta investigación-formación en la cibercultura, investigamos la mediación docente con los estudiantes de la disciplina Informática en la Educación, del curso Licenciatura en Pedagogía en la modalidad a distancia de la UERJ/CEDERJ/UAB durante el $2^{\circ}$ semestre del 2014. Para el presente artículo, optamos por interpretar los datos producidos en un foro de discusión de una de las clases de la disciplina. Como principal noción emergente de los análisis, llegamos al concepto de "Mediación docente en línea para la colaboración", que enfatiza la necesidad de una mediación activa y crítica para la promoción de la colaboración en línea..

PALABRAS CLAVE: Mediación docente en línea. Colaboración. Investigación-formación en la cibercultura.

\footnotetext{
${ }^{1}$ Doutora em Educação pela Universidade Federal da Bahia, UFBA - Brasil. Professora colaboradora da Universidade Aberta de Lisboa, UAB - Portugal. E-mail: edmeabaiana@gmail.com.

${ }^{2}$ Mestre em Educação pela Universidade do Estado do Rio de Janeiro, UERJ - Brasil. Professor coordenador do Centro Educacional da Lagoa, Rio de Janeiro, RJ - Brasil. E-mail: felipesilvaponte @ yahoo.com.br.

${ }^{3}$ Doutor em Informática pela Pontifícia Universidade Católica do Rio de Janeiro, PUC-RJ - Brasil. Professor adjunto da Universidade Federal do Estado do Rio de Janeiro, UNIRIO, Rio de Janeiro, RJ - Brasil. E-mail: pimentel@uniriotec.br.
}

Recebido em: 23/09/2015 - Aprovado em: 06/04/2016.

\begin{tabular}{l|l|l|l|l|l|l|} 
(C) ETD -Educ. Temat. Digit. & Campinas, SP & v.18 & n.2 & p. 23-42 & jan.abr.2016 & ISSN 1676-2592 \\
\hline
\end{tabular}




\section{ENSINO A DISTÂNCIA VERSUS EDUCAÇÃO ONLINE}

Os computadores em rede rapidamente se disseminaram por todo o sistema social e vêm provocando transformações em todos os setores da vida contemporânea. As novas práticas, modos de comunicação, organização e mobilização social, maneiras de viver e compartilhar o que se passa em nosso cotidiano com os usos das tecnologias digitais em rede, dão forma à cibercultura. Para Santos (2012, ONLINE), a cibercultura é "toda produção cultural e fenômenos sociotécnicos que emergiram da relação entre seres humanos e objetos técnicos digitalizados em conexão com a internet".

Esta reconfiguração sociotécnica vem alterando e ampliando os processos educativos, instituindo novos espaços online voltados para o processo de ensino-aprendizagem, emergindo nesse contexto diversas modalidades de ensino, dentre elas a EAD (educação a distância mediada pela internet), o E-learning (ensino totalmente online), o B-learning (ensino misto: online-presencial ou presencial-online) e o MOOC (curso online aberto e massivo). Esse novo cenário educacional tem reconfigurado principalmente a graduação no Brasil, pois se no início do ano 2000 praticamente não tínhamos cursos a distância, em uma década esta modalidade passou a ser responsável por quase $15 \%$ dos graduandos brasileiros (INEP/MEC, 2012).

Todas estas modalidades têm em comum o ensino massivo online. Muitos cursos são ofertados até sem mediação docente, e em tantos outros o docente desempenha o papel de emissor de conteúdos sem ou com pouca participação dos alunos. Muitos cursos de EAD adotam o modelo de tutoria reativa, com uma grande quantidade de alunos por professor, em que o docente só age quando é requisitado na sala virtual de tutoria para tirar alguma dúvida postada pelo aluno, ou fica de plantão no polo aguardando a visita de algum aluno com dúvidas. Estes modelos nos preocupam e nos parecem inadequados para a nossa sociedade contemporânea cibercultural.

Contrapondo as práticas massivas de ensino na EAD, que tem se tornado o modelo hegemônico, adotamos a abordagem da "educação online" (SANTOS, 2005; SANTOS; SILVA, 2009), que é concebida para promover a (co)autoria do aprendente, a mobilização da aprendizagem crítica e colaborativa, a mediação docente voltada para interatividade e partilha, traz a cibercultura como inspiração e potencializadora das práticas pedagógicas, visa a autonomia e a criatividade na aprendizagem. Em nossa concepção de educação online, o papel do docente é fundamental no processo formativo dos estudantes, sendo necessária uma mediação ativa para a promoção da aprendizagem colaborativa, que pressupõe a interatividade.

A presente pesquisa segue a metodologia da pesquisa-formação na cibercultura (SANTOS, 2005). A pesquisa-formação é uma metodologia de pesquisa em que o docentepesquisador pesquisa a sua prática como docente, não separando o ato educativo do ato de pesquisar. Para disparar os dados da pesquisa, constituído de imagens e narrativas produzidas pelos cursistas da disciplina Informática na Educação da UERJ/CEDERJ/UAB, foi criada 
uma ambiência pelo Moodle com variados recursos didáticos (textos, vídeos, fórum). Analisamos as conversas produzidas num dos fóruns de discussão da disciplina em questão, focalizando a mediação do tutor-pesquisador. Desta análise emergiu a noção de "mediação docente online para colaboração", conforme os achados apresentados neste artigo.

\section{FUNDAMENTOS DA EDUCAÇÃO ONLINE}

Na educação online, o docente deve promover a aprendizagem colaborativa, em que os estudantes aprendem juntos tornando-se corresponsáveis não apenas por sua própria aprendizagem, mas também pela aprendizagem dos colegas (CASTRO; MENEZES, 2011).

Colaboração é a realização em grupo de um trabalho visando alcançar um objetivo comum (FUKS et al., 2011). Os membros do grupo interagem e se influenciam, estabelecem relações sociais, desenvolvem processos para a realização de tarefas com o objetivo de alcançar metas compartilhadas. Alguns autores ressaltam que, para promover colaboração, é preciso atentar para três aspectos: comunicação, caracterizada pela troca de mensagens, pela argumentação e pela negociação entre pessoas; coordenação, caracterizada pelo gerenciamento de pessoas, atividades e recursos; e cooperação, caracterizada pela atuação conjunta no espaço compartilhado para a produção de objetos ou informações (ELLIS et al., 1991; FUKS et al., 2011).

"Comunicação", contudo, é um termo muito abrangente e também associado aos meios de comunicação de massa, em que um emissor envia uma mensagem (um conteúdo televisionado, um programa de rádio, uma notícia impressa) para vários receptoresespectadores, estabelecendo uma comunicação unidirecional, por difusão, sem a interação entre os sujeitos envolvidos nesse processo. Não é esse tipo de comunicação que se estabelece na colaboração. O termo mais adequado é "conversação", que é o tipo de comunicação tradicionalmente associado à conversação face-a-face, ao diálogo, à interatividade estabelecida entre os interlocutores, sendo os sujeitos ao mesmo tempo emissores e receptores das mensagens trocadas entre eles (CALVÃO et al., 2014).

A interatividade é um constructo importante para compreendermos a relação conversacional que os sujeitos estabelecem na colaboração; denota a construção colaborativa da mensagem e do próprio processo comunicacional, não separando os sujeitos da comunicação nas clássicas categorias de "emissor" versus "receptor". Silva (2009) enumera três características da interatividade:

\footnotetext{
a)participação-intervenção: participar não é responder sim ou não ou escolher uma opção dada, significa modificar a mensagem; b)bidirecionalidade-hibridação: a comunicação é produção conjunta da emissão e recepção, é cocriar, os dois polos codificam e decodificam; c)permutabilidade-potencialidade: a comunicação supõe múltiplas redes articulatórias de conexão e liberdades de trocas, associações e significações (SILVA, 2009, p. 32).
}

Muitos sistemas computacionais implementam um ou vários meios de conversação online (CALVÃO et al., 2014) dos quais o docente deve lançar mão para viabilizar a interatividade objetivada em seu desenho didático voltado para promover a aprendizagem colaborativa na educação online. Estes meios de conversação, arquitetados num desenho \begin{tabular}{l|l|l|l|l|l|l} 
(C) ETD-Educ. Temat. Digit. & Campinas, SP & v.18 & n.2 & p. 23-42 & jan.abr.2016 & ISSN 1676-2592
\end{tabular} 
didático, por si só não garantem a interatividade e a colaboração na formação dos cursistas, como problematizam Pimentel (2015) e Silva e coautores (2015). Apesar de o fórum de discussão ser um meio em que se estabelece a relação Todos-Todos entre os interlocutores (qualquer um pode enviar uma mensagem, e as mensagens enviadas são acessadas por todos), como ilustrado na Figura 1, pode ocorrer da conversação ficar centrada no professor, como esquematizado na Figura 2, algo intermediário entre o modelo Todos-Todos e Todos-Um, não ocorrendo a interatividade e a colaboração intencionadas no fórum.

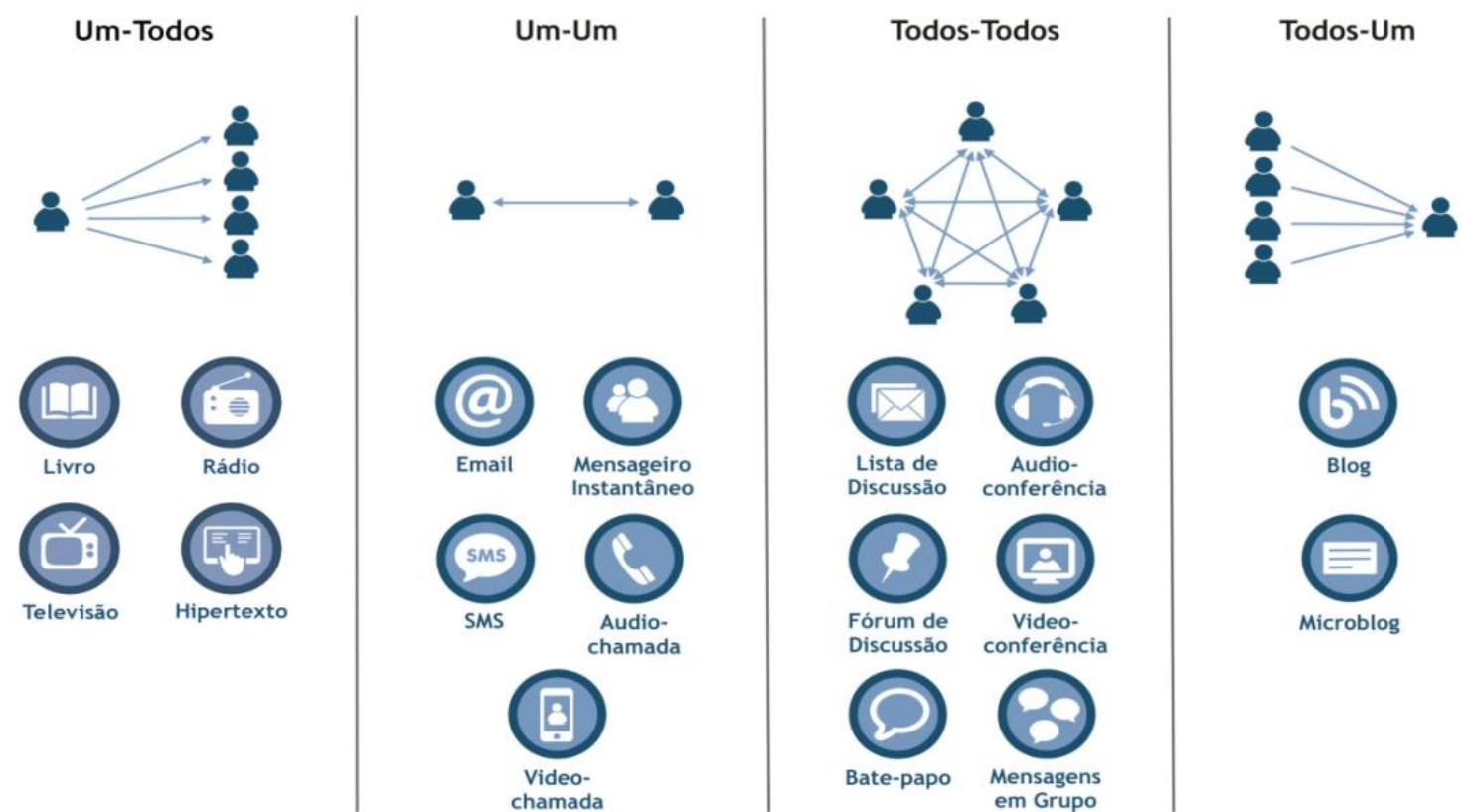

FIGURA 1 - Relação entre os interlocutores (baseado em CALVÃO et al., 2014)

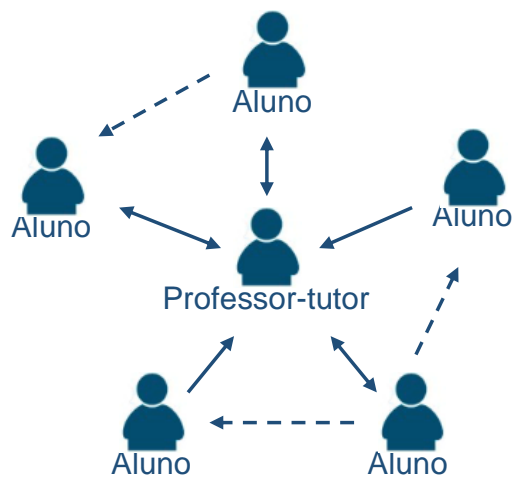

FIGURA 2 - Conversação centrada no professor-tutor (SILVA et al., 2015)

A mediação docente é determinante para promover a interatividade ou para tornar a conversação centrada no professor. Na aprendizagem colaborativa, a mediação docente desempenha a função de coordenação do grupo, sendo entendida por Bruno (2011, p. 116) "como uma ação coletiva fundada por meio da partilha e da colaboração interativa entre os sujeitos imbuídos nas constituições de redes de aprendizagem". A mediação docente é uma ação de coordenar as práticas dos estudantes na construção do conhecimento em grupo, de articular conversas com e entre os estudantes, cruzar ideias, mobilizar e partilhar reflexões e debates densos. O partilhar "é o movimento de produção de devires, olhares, percepções, ser 
e estar os devires latentes nas emergências daquele encontro, daquela acontecência" (BRUNO, 2011, p. 119). Na mediação partilhada, o docente deve incentivar a participação de todos, articular o diálogo entre os cursistas, trazer outras fontes de informação sobre o que se está sendo discutido, abrir conversas para outras discussões e oportunizar que os cursistas criem discussões entre si. Neste sentido, como diz Paulo Freire (1996), o docente deve respeitar a autonomia do educando e seus saberes, deve considerar que ensinar não é transferir conhecimento, mas sim estabelecer uma relação dialógica em que o diálogo se dá na "relação de A com B, nesta relação horizontal, nasce a matriz crítica, e não de A sobre B, antidiálogo, vertical” (FREIRE, 1967, p. 107).

Os pressupostos apresentados nesta seção fundamentam o desenho didático online e a mediação docente praticada pelos autores deste artigo. Na presente pesquisa-formação, são estes pressupostos teóricos que guiam a análise dos dados que produzimos nesta pesquisa conforme a metodologia apresentada a seguir.

\section{PESQUISA-FORMAÇÃO NA CIBERCULTURA}

Neste trabalho, abordamos a metodologia da pesquisa-formação na cibercultura a partir da nossa itinerância de pesquisa e docência, mais especificamente com a educação e docência online, concebidas por nós como fenômenos da cibercultura que se materializam em interface com as práticas formativas presenciais e online mediadas por tecnologias digitais em rede. Concebemos o processo de ensinar e pesquisar a partir do compartilhamento de narrativas, imagens, sentidos e dilemas de docentes e pesquisadores pela mediação das interfaces digitais que, para nós, são meios de conversação online concebidas como dispositivos de pesquisa-formação.

As interfaces digitais incorporam os aspectos comunicacionais e pedagógicos, bem como a emergência de um grupo-sujeito que aprende enquanto ensina e pesquisa, e pesquisa e ensina enquanto aprende. Na educação online, a aprendizagem ubíqua e seus dispositivos se configuram como espaços formativos de pesquisa e prática pedagógica em que são contempladas a pluralidade discursiva das narrativas e experiências pessoais, profissionais e acadêmicas dos praticantes culturais (SANTOS, 2014).

A pesquisa-formação é uma metodologia consolidada de pesquisa, mas reconhecemos que nossa autoria encontra-se exatamente na atualização de sua prática no contexto de docência na cibercultura (SANTOS, 2005, 2014). Nesse sentido, para nós, a pesquisaformação na cibercultura parte de alguns pontos bastante caros:

a) Com a cibercultura, novos arranjos espaçotemporais emergem e com eles novas práticas educativas. Sendo a cibercultura o contexto atual, não podemos pesquisar sem a efetiva imersão em suas práticas;

b) Pesquisar na cibercultura é atuar como praticante cultural produzindo dados em rede. Os sujeitos não são meros informantes, são praticantes culturais que produzem culturas, saberes e conhecimentos no contexto da pesquisa. Fazer pesquisa na cibercultura não é, para nós, apenas utilizar softwares para "coletar e organizar dados"; 
c) Não há pesquisa-formação desarticulada do contexto da docência. Nosso investimento é pesquisar em sintonia com o exercício docente e no ensino que investe na cibercultura como campo de pesquisa. Sendo assim, a educação online é contexto, campo de pesquisa e dispositivo formativo;

d) Educação online não é uma mera evolução das práticas massivas de EAD. Logo, não separamos os contextos educativos das cidades e seus equipamentos culturais (escolas, universidades, movimentos sociais, museus, organizações, eventos científicos, demais redes educativas), ainda mais em tempos de mobilidade ubíqua (SANTOS, 2005, 2014).

$\mathrm{Na}$ pesquisa-formação na cibercultura, docente-pesquisador online está implicado com a formação dos formandos que estudam, interagem, produzem e criam conhecimentos em rede, que são autores-atores de suas práticas, as quais ao mesmo tempo atravessam as práticas do formador-pesquisador e as transformam neste processo.

Na seção a seguir, apresentamos a construção da ambiência da pesquisa-formação na cibercultura, a ser retratada neste artigo. Tal ambiência se constitui pela elaboração de um desenho didático online, no qual se materializou pela mediação online colaborativa. Recortamos apenas uma aula da disciplina online "Informática na Educação", focalizando nossa atenção sobre o fórum de discussão por ser um meio de conversação privilegiado para a mediação online colaborativa.

\section{CAMPO E DISPOSITIVO DA PESQUISA-FORMAÇÃO}

A pesquisa-formação retratada neste texto é fruto de um estudo que se desenvolveu com os cotidianos dos cursistas e docentes online da disciplina "Informática na Educação", do curso de Licenciatura em Pedagogia a Distância da UERJ/CEDERJ/UAB, durante o primeiro e segundo semestres de 2014. A disciplina é ofertada em doze polos localizados em diferentes municípios do Rio de Janeiro. Cada docente-tutor online é responsável por fazer a mediação das atividades propostas aos estudantes de um determinado conjunto de polos.

A aula "O que é Cibercultura? Educando em nosso tempo!", retratada na Figura 3, revela os dispositivos arquitetados e acionados para promover práticas formativas mediadas pelo ambiente virtual de aprendizagem Moodle - para Ardoino, dispositivo é a "organização de meios materiais e/ou intelectuais, fazendo parte de uma estratégia de conhecimento de um objeto" (1998, p. 41). A aula foi organizada por eixos: artigos científicos; vídeos do YouTube da série "Cibercultura: o que muda na educação?" (elaborada pelo programa Salto para o Futuro, da TV Escola); e fóruns de discussão que agrupam alunos por polos a serem mediados por um tutor-professor. 


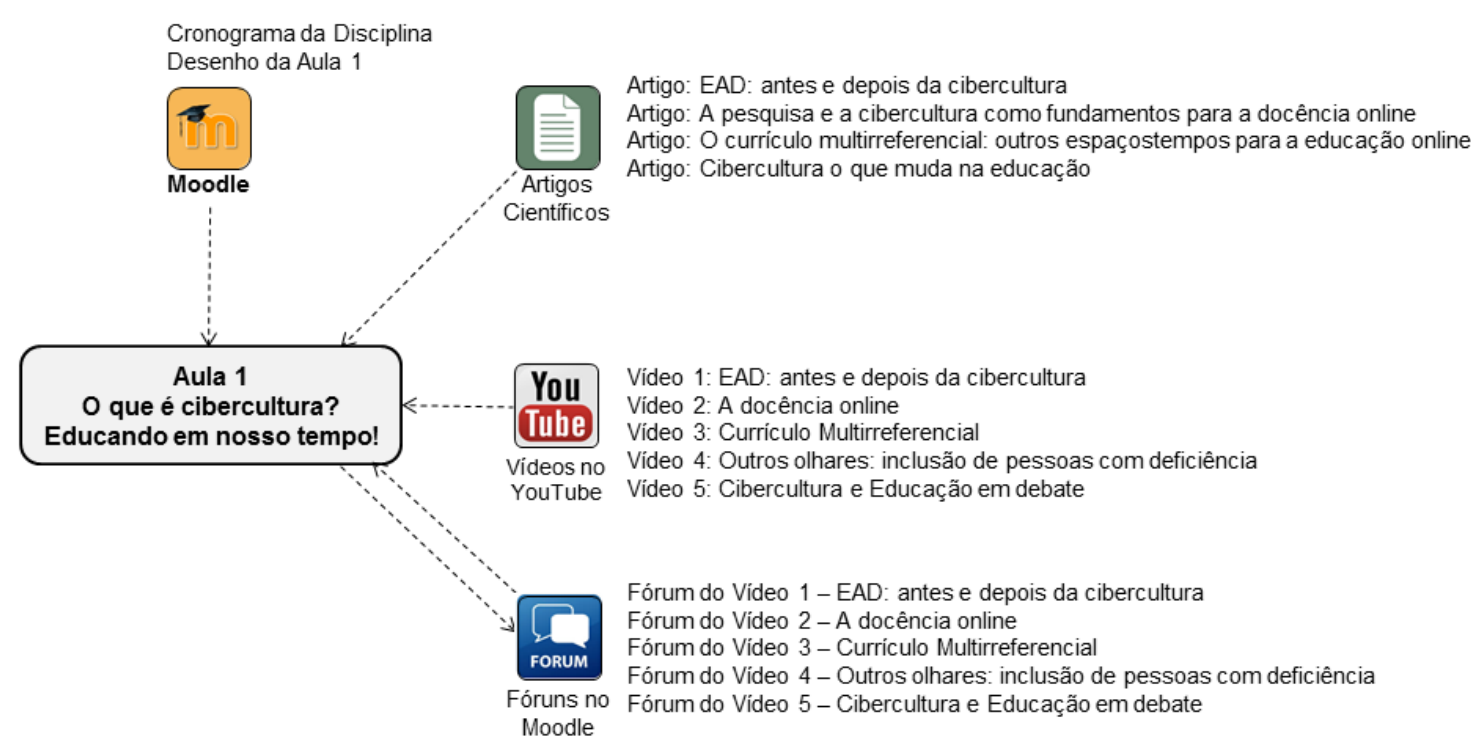

FIGURA 3 - Recursos mobilizados na Aula 1

Foram abertos cinco fóruns, cada um referente a um vídeo. A escolha pelo uso do "fórum de discussão" decorre da necessidade de criar espaços para conversas em profundidade para que o(a)s praticantes pesquisado(a)s exponham suas reflexões, tragam seus dilemas, inquietações, práticas e experiências no compartilhamento coletivo, discutindo uns com os outros.

As conversas disparadas estão analisadas na próxima seção. Buscamos fazer uma leitura interpretativa dos dados, revelando significados, recorrências, relações estruturadas, contradições. Esta análise é realizada com o objetivo de fazer emergir noções subsunçoras que, para Santos (2005, p. 153), "são categorias analíticas da análise e interpretação dialógica entre empiria e teoria". Para apoiar a análise dos dados, nesta pesquisa também foram usadas técnicas de Análise da Conversação Mediada pela Computação (RECUERO, 2012) e técnicas de Análise de Redes Sociais (WASSERMAN e FAUST, 1994; MEIRE et al., 2011; RECUERO et al., 2015), que possibilitam produzir medidas quantitativas para apoiar as análises interpretativas ou mesmo dispará-las, resultando numa análise quali-quanti.

As técnicas de Análise da Conversação Mediada pela Computação fundamentam-se na Análise da Conversação, que é uma abordagem originalmente elaborada para estudar a interação social, abrangendo a conversação verbal e não verbal em situações do cotidiano, sendo uma abordagem estabelecida e usado em várias áreas como linguística, sociologia, antropologia e psicologia. A conversação é o gênero mais básico da interação humana e está associada ao cotidiano de todos nós, e por isso é tão importante compreendermos como ela se realiza e se transforma nos meios de conversação da Internet, sendo o foco de estudo da área interdisciplinar que classicamente era denominada de Comunicação Mediada por Computador (CMC), que estuda os fenômenos emergentes do uso de sistemas computacionais que medeiam a conversação humana, focando tradicionalmente nos aspectos técnicos (sistemas e serviços computacionais), linguísticos (linguagem que emerge nesses meios), culturais (novas práticas) e sociais (estabelecimento e ressignificação das relações sociais). Com o estabelecimento da noção de ciberespaço, principalmente como um espaço de \begin{tabular}{l|l|l|l|l|l|l} 
(C) ETD-Educ. Temat. Digit. & Campinas, SP & v.18 & n.2 & p. 23-42 & jan.abr.2016 & ISSN 1676-2592
\end{tabular} 
conversação online, o que antes era conhecido como CMC se tornou e se ressignificou no que contemporaneamente reconhecemos como Cibercultura.

Já as técnicas de Análise das Redes Sociais (Social Network Analysis) estudam as relações sociais entre atores visando compreender os padrões e as implicações destas relações. Os sociólogos foram os primeiros a estudar as redes sociais com o objetivo de entender os relacionamentos humanos, e já na década de 1940, os cientistas passaram a representar as relações humanas na forma de grafo, denominado sociograma, e os matemáticos e estatísticos começaram a aplicar a teoria de grafos para definir métricas úteis para investigar a rede social, o que originou o campo da Análise de Redes Sociais (MEIRA et al., 2011). A análise das redes sociais é aplicada em várias áreas do conhecimento, e na presente pesquisa utilizaremos para investigar a rede social emergente da conversação que se realizou num fórum da Aula 1. Na presente pesquisa, produzirmos medidas e visualizações utilizamos o NodeXL, que "é um pacote de software gratuito e aberto para análise e visualização de redes sociais que se integra ao Microsoft Excel. Este é um software popular, similar a outras ferramentas de visualização de redes tais como Pajek, UCINet e Gephi" (NODEXL, 2015).

Foram nos movimentos das competências teóricas e analíticas, visando a apreensão fina da realidade do cotidiano desta pesquisa com os cursistas da disciplina Informática na Educação e com o docente online tutor-pesquisador, que emergiu a noção subsunçora "mediação docente online para colaboração", conforme discutiremos nas próximas seções.

\section{INTERATIVIDADE/COLABORAÇÃO NO FÓRUM}

Para análise neste artigo, fizemos um recorte da conversação ocorrida num dos fóruns do segundo semestre de 2014 da disciplina Informática em Educação, cujas primeiras mensagens encontram-se transcritas no Texto 1. Este fórum teve como base o vídeo "EAD: antes e depois da cibercultura".

O fórum de discussão, junto com o email e o bate-papo, são os meios de conversação mais utilizado dos Ambientes Virtuais de Aprendizagem (CENSO, 2013, p.133). Contudo, Silva e co-autores (2015) e Pimentel (2015) problematizam que a interação nos meios de conversação online, quando usados no contexto educacional, nem sempre promovem a interatividade e a colaboração. De fato, temos observado que é muito frequente o fórum ser usado no contexto da EAD como uma espécie de questionário com perguntas abertas, onde o tutor coloca perguntas que devem ser respondidas pelos alunos, sem promover uma conversação autêntica entre eles, sendo o fórum usado numa perspectiva instrucionista, em que muitas vezes a mediação do tutor objetiva corrigir a conceituação dos alunos, indicar mais conteúdo ou apresentar novas questões a serem respondidas por todos. Não é nesta concepção que compreendemos o uso de fórum no contexto da educação online. O tutorpesquisador, em sua mediação no fórum, deve promover a interatividade fazendo os alunos conversarem entre si colaborando para a construção conjunta do conhecimento em questão, o que pode ser identificado no Texto 1 a seguir. 
Fórum 1 - EAD: antes e depois da cibercultura

Felipe (Tutor-pesquisador)

Olá pessoal!

Bem-vindos ao fórum 1 !

A partir dos conteúdos abordados no vídeo "EAD: antes e depois da cibercultura" e dos textos disponibilizados, vamos discutir juntos: como podemos compreender a cenário sócio-técnico contemporâneo (cibercultura)? $\mathrm{O}$ que mudou na educação ? Como é a prática da EAD na cibercultura?

\title{
Rita
}

Boa noite!

Assistindo ao vídeo e fazendo a leitura sobre o mesmo, cheguei as seguintes conclusões:

Cibercultura > conexão de várias redes utilizando as mais variadas tecnologias digitais. Essa conexão afeta a sociedade e os espaços sociais.

EAD > sempre existiu, porém de forma diferente como hoje em dia. Hoje este ensino faz uso das diferentes dimensões da linguagem - textual, imagética, sonora...O aluno passa a não ser mais um mero receptor dos conteúdos - ele se torna parte de um processo ativo de ensino aprendizagem, exigindo dele mais disciplina e empenho para obter sucesso em seu aprendizado.

Cibercultura e educação > com as novas tecnologias, tudo se modifica na educação. É necessário que o professor acompanhe o processo de inovação na educação para aprimorar seu ensino em sala de aula. $O$ aluno começa a ter acesso a uma vasta rede de informações e isso pode e deve ser transformado em aprendizado em aula.

\section{Felipe (Tutor-pesquisador)}

Olá pessoal!

Rita, sua narrativa está muito boa!

Complementando ela, para a professora Edméa Santos (2012), "a cibercultura é toda produção cultural e fenômenos sociotécnicos que emergiram da relação entre seres humanos e objetos técnicos digitalizados em conexão com a internet, a rede mundial de computadores".

A autora está querendo chamar a nossa atenção para as nossas práticas e ações contemporâneas com as tecnologias digitais em rede, onde nestes entrelaçamentos, nós reconfiguramos os modos como nos comunicamos, criamos, produzimos, estudamos, trabalhamos etc.

SANTOS, Edméa (2012). Link da fonte:

http://www.comciencia.br/comciencia/handler.php?section=8\&edicao=74\&id=932

\begin{abstract}
Juciane
Após os estudos, concluo que Cibercultura pode ser entendida como cultura executada pelos indivíduos na atualidade, mediada por tecnologias digitais em rede; utiliza-se de uma comunicação versátil, rápida, que alcança pessoa independente da distancia entre elas.

Acarreta várias mudanças na educação, mas o que posso ressaltar é a oportunidade de um maior número de pessoas, concluírem seus estudos, por causa da praticidade de acessar as informações. A prática da EAD na Cibercultura tem sido desenvolvida com constantes estudos, durante sua prática e isso contribui para uma crescente credibilidade para este setor, impulsionando cada vez mais, melhores resultados de aprendizagem.
\end{abstract}

\section{Therezinha}

Oi Juciane!

Acredito que a cibercultura auxilia tanto os jovens quanto aos adultos pela busca de informações, contribuindo bastante na área educacional com a prática das EAD. Porém existem alguns aspectos negativos que devem ser observados, os jovens tende a se distanciar dos seus familiares próximos e se conectar com os amigos online. Um abraço.

\section{Juliana}

Concordo com você, quando ressalta os dois lados da moeda nas questões de cibercultura. Percebemos que ao mesmo tempo em que o rápido avanço tecnológico tem unido e facilitado à comunicação, também tem sido a causa de distanciamento de muitos. Não podemos negar os grandes benefícios que surgem através do avanço das tecnologias de informação.

O avanço da EAD proporcionado pelas novas tecnologias é um marco para a educação, desde que, alcança pessoas que de repente, por inúmeros motivos, não teriam a possibilidade de ingressar em uma faculdade, agregando muitos conhecimentos por meio da interatividade, e nós somos exemplo deste fato.

Estamos tendo a oportunidade de construir conhecimento através deste meio de comunicação, juntamente com nossos colegas que interagem nestes fóruns.

Desta forma, podemos compreender melhor os benefícios da cibercultura em nossos dias atuais e a importância de levar essa ferramenta para nossos alunos e nossas aulas.

Porém, sempre surge a apreensão de como trabalhar com o avanço das tecnologias na 
escola.

Existe o receio por parte de muitos educadores por não dominarem tais tecnologias, como também a preocupação de não encontrar o equilíbrio na utilização das mesmas. Se utilizarmos demais, será que banalizaremos o contato, a comunicação e interação que deve existir em sala de aula? E por outro lado, a pouca utilização afastará os alunos de nós e do interesse pelas aulas, já que a tecnologia faz parte da vida dos jovens? Então, emerge a questão: Como encontrar esse equilíbrio no mundo da cibercultura? Como aproximar os alunos do conhecimento por meio da exploração de um mundo em que eles estão totalmente conectados?

\title{
Felipe (Tutor-pesquisador)
}

Olá Rita, Juciane, Therezinha, Juliana e demais colegas, estou gostando de ver esse nosso início de conversa!

Rita, sua narrativa está muito boa!

Complementando ela, para a professora Edméa Santos (2012), "a cibercultura é toda produção cultural e fenômenos sociotécnicos que emergiram da relação entre seres humanos e objetos técnicos digitalizados em conexão com a internet, a rede mundial de computadores".

A autora está querendo chamar a nossa atenção para as nossas práticas e ações contemporâneas com as tecnologias digitais em rede, onde nestes entrelaçamento, nós reconfiguramos os modos como nos comunicamos, criamos, produzimos, estudamos, trabalhamos etc.

SANTOS, Edméa (2012). Link da fonte: http://www.comciencia.br/comciencia/handler.php?section=8\&edicao=74\&id=932

Juciane, dialogando com a sua fala, quando você diz: "em relação ao número de pessoas fazendo cursos na modalidade EAD", lembrei-me de uma reportagem do Senac falando que a "EAD cresce e aparece no Brasil".

Vale muito a pena conferir, indico a leitura!

Segue o link da reportagem: http://www.ead.senac.br/noticias/2013/12/ead-cresce-eaparece-no-brasil/

Terezinha, como nós podemos compreender e mudar esses aspectos negativos? Confesso que não tenho respostas, mas nada melhor que uma boa conversa para começar.

\begin{abstract}
Juliana, gostei muito da sua fala nesse início de discussão, assim como as suas questões. Sou suspeito para responder elas, sou professor de informática no ensino fundamental e aqui na graduação. Porém, compartilho com você e com todos um pouco das minhas dinâmicas na sala de informática na escola, para ajudar a compreender a correria do cotidiano escolar, nos quinze primeiros minutos de aula, eu deixo os alunos livres para jogar, ver vídeo, usar o googlemaps, dentro outros. Durante esse período, ainda estou recebendo os alunos que estão saindo das suas salas e chegando à sala de informática, daí vou fazendo a chamada, vejo o que eles estão conversando, interajo nas conversas deles e depois começo abordar os conteúdos da aula. Assim, eu vou me equilibrando, pois eles já chegam me cobrando os quinze minutos de aula livre rsrs.
\end{abstract}

\section{Ana}

O que muda na educação em tempos de cibercultura é que facilita o professor, que pode estimular as aulas de várias maneiras. E assim, influenciando o seu modo de aprender e ensinar, trazendo possibilidades de ampliar a leitura de seus alunos. Portanto, melhorando a qualidade de ensino cada vez mais.

\section{Marcia}

Olá Ana! bem... eu entendo que a Cibercultura trouxe para a ead uma interação mais rápida, do que antes dela, pode-se acessar informações e conteúdos quase que em tempo real, isso facilita a vida daqueles, como nós, que por motivos variados estudam à distância; antes da cibercultura todo o processo de ensino aprendizagem era mais demorado, dependia de enviar e receber correspondências que às vezes eram demoradas, apesar de que essa prática era moderna para aquela época, muitos profissionais capacitados venceram esses obstáculos e conseguiram terminar os cursos, tenho exemplo do meu pai que fez curso técnico em rádio, por correspondência.

Com a cibercultura podemos participar de grupos, palestras, debates etc...sem estarmos numa sala de aula física, nesse ambiente virtual acontece a troca de conhecimentos, recebemos e também 
ensinamos, assim o aprendizado se propaga; o aluno da ead, para ter bons resultados, precisa ser disciplinado e focado, para não se perder pelo caminho, e o professor deve estar atualizado e inovando em sua prática, para estimular os alunos com técnicas e recursos atuais, pois as tecnologias avançam de uma forma muito rápida, essa modalidade estimula a construção do conhecimento.

\section{Danielle}

Marcia, penso que a cibercultura entrou pela nossa geração como uma forma de nos manter literalmente conectados com tudo que há ao nosso redor. Me recordo dos meus estudos a partir do 6ํano, onde várias pesquisas eram solicitadas e nós tínhamos que nos deslocar até uma biblioteca pública mais próxima e realizarmos inúmeras atividades de leitura sem saber se o conteúdo daquele livro em específico iria contemplar as nossas indagações, atualmente os alunos de forma geral tem acesso a quaisquer informações a um click de distância. Também é possível aos educandos da atualidade acessar a museus, obras de arte e uma infinidade de opções de acesso à cultura.

\section{Viviane}

Danielle,

Lendo seu comentário, penso em minha sobrinha que com apenas 05 anos já sabe ligar o computador, entrar em alguns sites. Isso me faz concluir como a cibercultura tomou um grande espaço em nossas vidas, uma vez que quando eu tinha a mesma idade dela, não sabia o que era um computador. Parece que as crianças de hoje já nascem sabendo manusear um computador ou um telefone de última geração. Assim vejo que a escola não pode ficar de fora dessa. Deve aproveitar também essa tecnologia para desenvolver o processo de aprendizagem para atrair os alunos, que só pensam na tecnologia. Abraços!

\section{Alessandra \\ Com a revolução digital, passamos a conviver e a nos adaptar ao mundo que está em constante mudança. Passamos de consumidores a produtores e distribuidores de informação. Informações e conhecimentos são produzidos e compartilhados sem custos excessivos através das redes sociais. Foi através desta intensa produção/troca, interatividade que a educação a distância passou a se desenvolver mais.}

\section{Felipe (Tutor-pesquisador)}

Olá Marcia, Alessandra, Danielle, Viviane e turma!

Estou gostando de ver as conversas de vocês!

Marcia, a sua fala traduz um pouco do processo evolutivo da EAD. Vale ressaltar, que a quinta geração da EAD mediada pelo digital em rede não é sinônimo de educação online, como podemos analisar nos vídeos e nos textos desta aula.

A educação online se inspira nas práticas ciberculturais: interação, colaboração, compartilhamento, participação coletiva, para pensar-fazer as práticas pedagógicas.

As práticas da EAD, mesmo online, estão voltadas para a lógica das mídias de massas, a prática é unidirecional, focada nos conteúdos, tutoria reativa.

Danielle e Viviane, as narrativas de vocês são ótimas! Lendo, me lembrei das minhas aulas de informática, era tudo muito instrumental, aprendi a criar e compactar arquivos, pastas, mexer no pacote windows, etc.

Colaborando com as falas de vocês duas, hoje, temos outras dinâmicas de sala de aula, mais interfaces para fazer uso pedagógico, a conexão com a internet é melhor, a quantidade de jogos para participar em rede é enorme, mais os sistemas de rede sociais como Facebook, YouTube, a informação está ao nosso alcance de forma rápida, os novos livros didático estão online nos sites das editoras com jogos, vídeos, imagens, dentre outras.

Alessandra, gostei muito da sua fala quando diz: "Passamos de consumidores a produtores e distribuidores de informação. Informações e conhecimentos são produzidos e compartilhados sem custos excessivos através das redes sociais." A partir dela podemos levantar algumas questões:

Como são vistos os aparelhos celulares e como usá-los em nossas práticas? Vamos pensar todos juntos!

Rita

Boa noite!

O professor e a escola tem que compreender que cada vez mais a 
tecnologia está avançando para as salas de aula. E isso não é privilégio somente de escolas em bairros nobres, mas escolas em comunidades carentes também. Seja por projetos em escolas públicas ou em lan houses, os alunos têm acesso ao mundo digital e isso vai influenciar seu aprendizado. Vejo que, cabe à comunidade escolar, compreender isto e utilizar a seu favor. Promover pesquisas, incentivar o uso educacional das mídias digitais, promover debates sobre os prós e contras da internet, são algumas formas de utilizar o avanço da tecnologia a favor da educação.

\section{Maria}

\section{Olá!}

A questão das escolas e o uso das tecnologias em sala de aula tem tido um avanço tímido se comparado com a dinâmica tecnológica do contexto social fora das salas. A prova se tem quando se cria uma lei contra celulares em sala de aula. Não seria mais racional capacitar o professor para utilizar essa ferramenta em favor da autonomia do aluno no processo de aprendizagem? Pois os alunos estão conectados o tempo todo, sendo assim esse processo seria dinamizado facilitando o acesso as informações relacionadas às disciplinas.

Seu apontamento sobre a questão de celulares em sala de aula é bem proposital, pois observo que as maiorias das escolas não aproveitam essa tecnologia. Os aparelhos celulares tem uma infinidade de recursos que ajudariam no processo de aprendizagem dos alunos, tornando - os mais autônomos. Um dos pontos positivos dessa ferramenta em sala seria a dinâmica da construção do conhecimento pelo próprio aluno, Um dos pontos negativos seria a falta de conhecimento do professor, de como utilizar essa ferramenta para orientar o aluno nesse processo.

6 Hoje o que se pode observar é que o aluno tem seu aparelho confiscado, caso seja usado em sala de aula.

60 Como facilitadores de conhecimento, precisamos rever nossos conceitos sobre essa tecnologia em sala.

$\Theta$ vale refletir sobre o assunto!

\section{Ionara}

Oi Maria, tenho observado este comportamento na escola do meu filho, ele está no Ensino Médio, o uso do celular é proibido em todas as áreas da escola, penso que deveriam buscar alternativas para o uso e aproveitamento desta ferramenta, já que a mesma parece fazer parte do corpo desta nova geração, então porque não utilizá-la como recurso pedagógico, o natural é que eles (nova geração) continuem mergulhando neste universo tecnológico, nós professores que devemos refletir e buscar caminhos para que este aparelho seja utilizado nas salas de aula como um caminho que ampliará o conhecimento do aluno.

\section{Viviane}

Boa Noite Felipe e colegas,

Pelas minhas experiências em sala de aula, vejo que por mais que se fale da tecnologia como aliada à educação, ainda vejo muitas resistências das escolas e também a pouca maturidade dos alunos para o acesso, como por exemplo, do celular como ferramenta de aprendizagem.

\section{Gabriela}

Eu penso que as tecnologias usadas pelos professores durante as aulas podem ajudar a estabelecer um elo entre conhecimentos acadêmicos, com os adquiridos e vivenciados no cotidiano do aluno, ocorrendo assim transições de experiência. 
TEXTO 1 - Transcrição das primeiras mensagens do Fórum 1

No fórum transcrito no Texto 1, os cursistas não se restringiram a dar uma resposta para a questão apresentada inicialmente, mas sim conversaram a partir da fala do outro, complementando e aprofundando a discussão. Pela análise das narrativas, pode-se compreender que a conversação entre os alunos foi de fato genuína: muitos apresentaram reflexões sobre a própria prática para analisar e discutir a questão abordada no fórum, fazendo conexões com as falas dos colegas.

Este padrão, contudo, não é o que muitas vezes acontece nos fóruns que se realizam no contexto da EAD. O docente que tem uma perspectiva mais instrucionista, exercerá uma mediação no fórum que induzirá os alunos a apresentarem uma conceituação formal e fora de contexto, e assim muitos alunos até copiam e colam textos que encontram na Internet. Já na perspectiva mais autoral, a que praticamos, o diálogo precisa ser genuíno, contextualizado, e assim o aluno não se sente na obrigação de produzir textos conceitualmente corretos, pois entende que o fórum é para apoiar a sua formação, e produzir narrativas relacionando a questão em discussão com suas próprias reflexões e experiências. Nesta perspectiva, até chama atenção quando não está clara a autoria do aluno, como é de se estranhar a mensagem de Alessandra que apresenta uma análise elaborada, mas aparentemente desvinculada de seu contexto e de todo o resto da conversação: "Com a revolução digital, passamos a conviver $e$ a nos adaptar ao mundo que está em constante mudança. Passamos de consumidores a produtores e distribuidores de informação (...)”. Perante esta mensagem, o tutor Felipe valorizou a participação mas provocou a aluna para que ela fizesse uma análise a partir de suas próprias práticas: "Alessandra, gostei muito da sua fala (...) A partir dela podemos levantar algumas questões: Como são vistos os aparelhos celulares e como usá-los em nossas práticas? Vamos pensar todos juntos!". Com esta prática de mediação docente, chamando os alunos para participarem genuinamente da conversa, com autoria visando a construção colaborativa de um conhecimento sobre a questão em discussão, que o tutor vai desconstruindo as práticas tradicionais que os alunos já até adquiriram ao participar de outros fóruns no contexto educacional, e vai mostrando e construindo com eles novos processos de discussão autêntica.

Para caracterizar a conversação ocorrida neste fórum, analisamos sua estrutura com apoio das técnicas da Análise da Conversação Mediada por Computador. No fórum, a partir da mensagem inicial do tutor, toda nova mensagem é enviada como uma resposta para alguma mensagem anterior, e assim a nova mensagem fica associada com a mensagem respondida, sendo apresentada visualmente no Texto 1 com um recuo para a direita, indentada em relação à mensagem respondida. O resultado é uma estrutura hierárquica de mensagens associadas, que denominamos de Árvore de Discussão, conforme ilustra a Figura 4, que é uma abstração e mapeamento da discussão transcrita no Texto 1. Representamos cada mensagem como um quadrado contendo o nome do autor; por exemplo, a primeira mensagem do fórum, enviada pela tutor-pesquisador Felipe, é representada como o primeiro quadrado, da esquerda para direita, contendo o rótulo "Felipe(1)". Uma associação entre mensagens é representada por uma seta, assim a mensagem B que responde a mensagem A é 
representada por $\mathrm{B} \rightarrow \mathrm{A}$; por exemplo, a primeira resposta dada por Rita está representada na Figura 4 pela associação Rita(1) $\rightarrow$ Felipe(1).

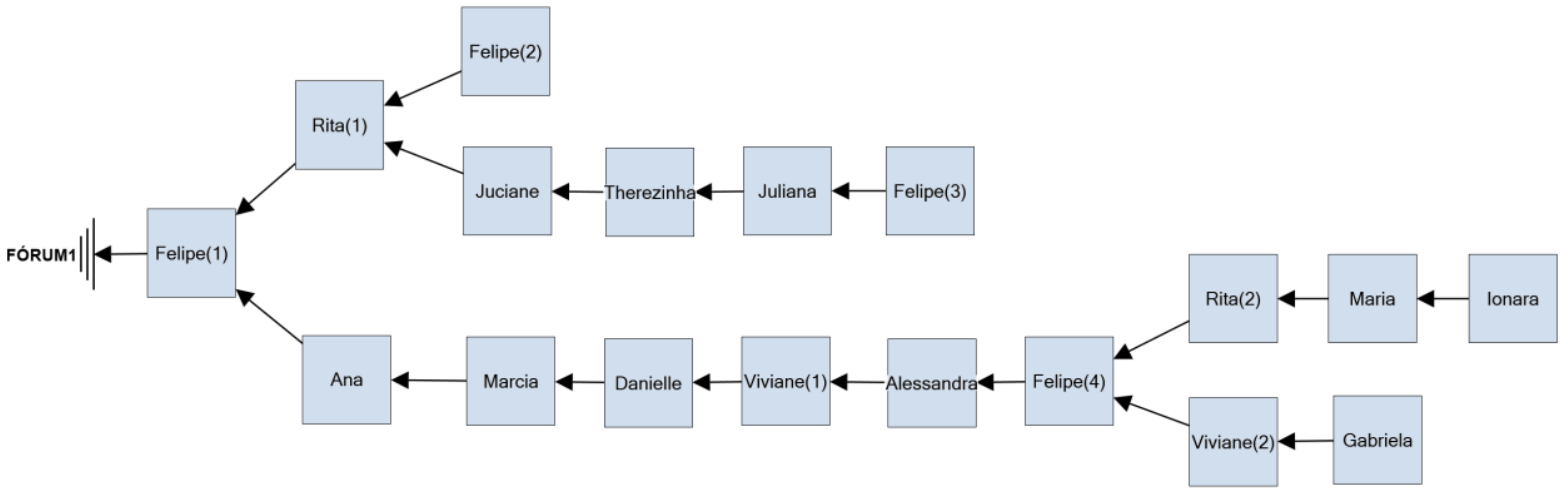

FIGURA 4 - Árvore da Discussão mapeada no Texto 1

A partir da Árvore de Discussão representada na Figura 4, visualmente constatamos que somente Rita e Ana enviaram uma resposta para a questão inicial do fórum apresentada na mensagem "Felipe(1)". Se fossem dadas várias respostas para a mensagem inicial do fórum, seria um sintoma de que o fórum estaria sendo usado como uma espécie de questionário aberto, mas não é isso o que se visualiza na estrutura de mensagens deste fórum em análise. Pelo contrário, identifica-se que os alunos responderam uns aos outros, desdobrando e aprofundando a discussão, sendo um indício de que a interatividade e colaboração ocorreu neste fórum. O nível médio da profundidade desta discussão foi 5,3, conforme apresentado na Figura 5, o que é alto se comparado a outros fóruns como os analisados por Gerosa e co-autores (2003). Isto significa que os alunos desencadearam uma discussão em profundidade, dando continuidade ao discurso uns dos outros, não se restringindo a responder apenas a pergunta inicial apresentada no fórum (o que resultaria numa conversação com pouca profundidade).

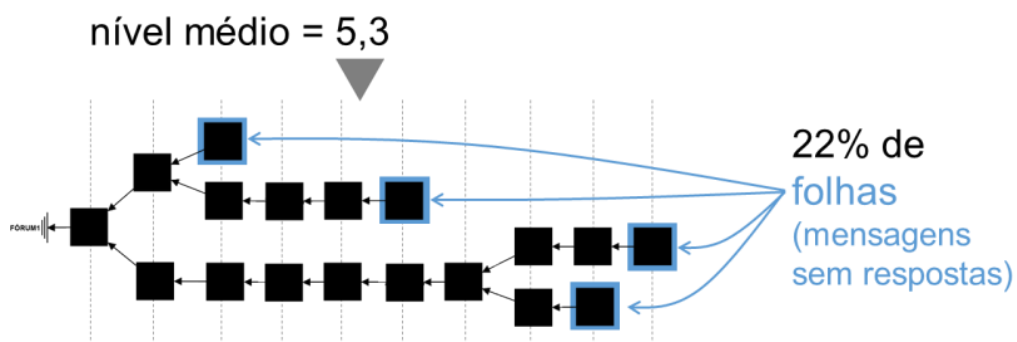

\section{$\begin{array}{llllllllll}1 & 2 & 3 & 4 & 5 & 6 & 7 & 8 & 9 & 10\end{array}$}

\section{profundidade da discussão}

FIGURA 5 - Análise do nível de profundidade e percentual de folhas da Árvore da Discussão (mapeada a partir do Texto 1)

Também a partir da análise apresentada na Figura 5, pode-se visualizar que poucas mensagens ficaram sem alguma resposta (apenas 4 folhas nesta árvore, de um total de 18 mensagens enviadas no fórum, significando que apenas $22 \%$ das mensagens ficaram sem 
respostas). De certo modo é frustrante para o aluno ter uma mensagem que não foi comentada por ninguém. Por isso o tutor-pesquisador frequentemente respondia comentando as mensagens dos alunos, buscando valorizar o que cada um havia trazido para a discussão e também chamando os demais para participarem daquela trilha da conversa.

TABELA 1 - Medidas da conversação obtidas do Texto 1 e da FIGURA 4

\begin{tabular}{|l|c|c|}
\hline Participante & $\begin{array}{c}\text { Qtd. de mensagens enviadas pelo } \\
\text { participante (postagens) }\end{array}$ & $\begin{array}{c}\text { Qtd. de mensagens endereçadas } \\
\text { ao participante (respostas recebidas) }\end{array}$ \\
\hline Felipe (tutor) & 4 & 4 \\
\hline Alessandra & 1 & 1 \\
\hline Ana & 1 & 1 \\
\hline Danielle & 1 & 0 \\
\hline Gabriela & 1 & 0 \\
\hline Ionara & 1 & 1 \\
\hline Juciane & 1 & 1 \\
\hline Juliana & 1 & 1 \\
\hline Marcia & 1 & 1 \\
\hline Maria & 2 & 3 \\
\hline Rita & 1 & 1 \\
\hline Therezinha & 2 & 2 \\
\hline Viviane & 1 & 1 \\
\hline
\end{tabular}

Para investigar se o tutor se tornou o centro deste fórum, a partir da Figura 4 contabilizamos a quantidade de mensagens enviadas por cada participante e quantas mensagens foram endereçadas a cada participante como respostas às mensagens que enviou, e assim produzimos os dados apresentados na TABELA 1.

Com estes dados, identifica-se que o tutor Felipe enviou 4 mensagens, se diferenciando muito dos demais participantes. De fato, verificamos que a quantidade de mensagens produzidas pelo Felipe se caracteriza como um "ponto fora da curva" (outlier). Matematicamente, um ponto fora da curva é um valor discrepante, fora do normal comparado com os demais valores do conjunto, o que é identificado pelo teste de diagrama de caixas (DIAGRAMA; 2015, OUTLIER, 2015, GRAPHPAD, 2015). Esta análise indica que, de fato, Felipe falou bem mais que os demais participantes. Este comportamento chama atenção, pois pode indicar que o tutor está monopolizando a conversa, um sintoma de uma postura instrucionista do professor que se coloca no papel de detentor do conhecimento e se sente na necessidade de falar-ditar para os alunos assimilarem o máximo de conteúdo possível. Contudo, a partir da análise qualitativa, identifica-se que não é esta a postura desempenhada na mediação de Felipe. O tutor-pesquisador buscou valorizar as falas autênticas dos alunos, suscitava a reflexão e chamava os demais para a participação e aprofundamento da conversa, sem com isso querer ditar conteúdo a ser assimilado pelos alunos. A grande quantidade de mensagens produzidas pelo tutor-pesquisador, neste caso, indica uma mediação muito ativa para coordenar a ação do grupo na construção colaborativa do conhecimento. 
Por outro lado, ao analisarmos a quantidade de mensagens endereçadas a cada participante, constatamos que também foram endereçadas 4 mensagens para o tutorpesquisador, mas este valor não é muito discrepante dos demais, por exemplo, a aluna Rita recebeu 3 respostas. Isto significa que o tutor-pesquisador não se tornou o centro das atenções daquela conversa, todos receberam atenção de forma normal, não se caracterizando numa conversa centrada no tutor-pesquisador, o que, infelizmente, nem sempre acontece nos fóruns realizados no contexto da educação a distância.

A partir da árvore da conversação, mapeamos a "rede social que emerge da conversação" (RECUERO, 2012, p. 143), abstraída e representada no grafo ilustrado na Figura 6 (sociograma). Esta outra estrutura representa os interlocutores e suas relações. Quando um participante responde uma mensagem, consideramos que o autor da nova mensagem está se relacionado com o autor da mensagem que está respondendo. Por exemplo, na primeira trilha daquela conversa, Rita respondeu a primeira mensagem enviada por Felipe, que por sua vez respondeu essa primeira mensagem de Rita. Enquanto na Figura 4

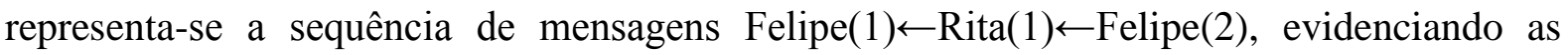
associações entre as mensagens que promoveram o desdobramento do discurso, na Figura 4 representa-se a relação estabelecida entre os interlocutores Felipe $\leftrightarrow$ Rita, neste caso com seta em ambos os lados indicando que tanto Rita respondeu Felipe (Rita $\rightarrow$ Felipe) quanto Felipe respondeu Rita (Felipe $\rightarrow$ Rita).

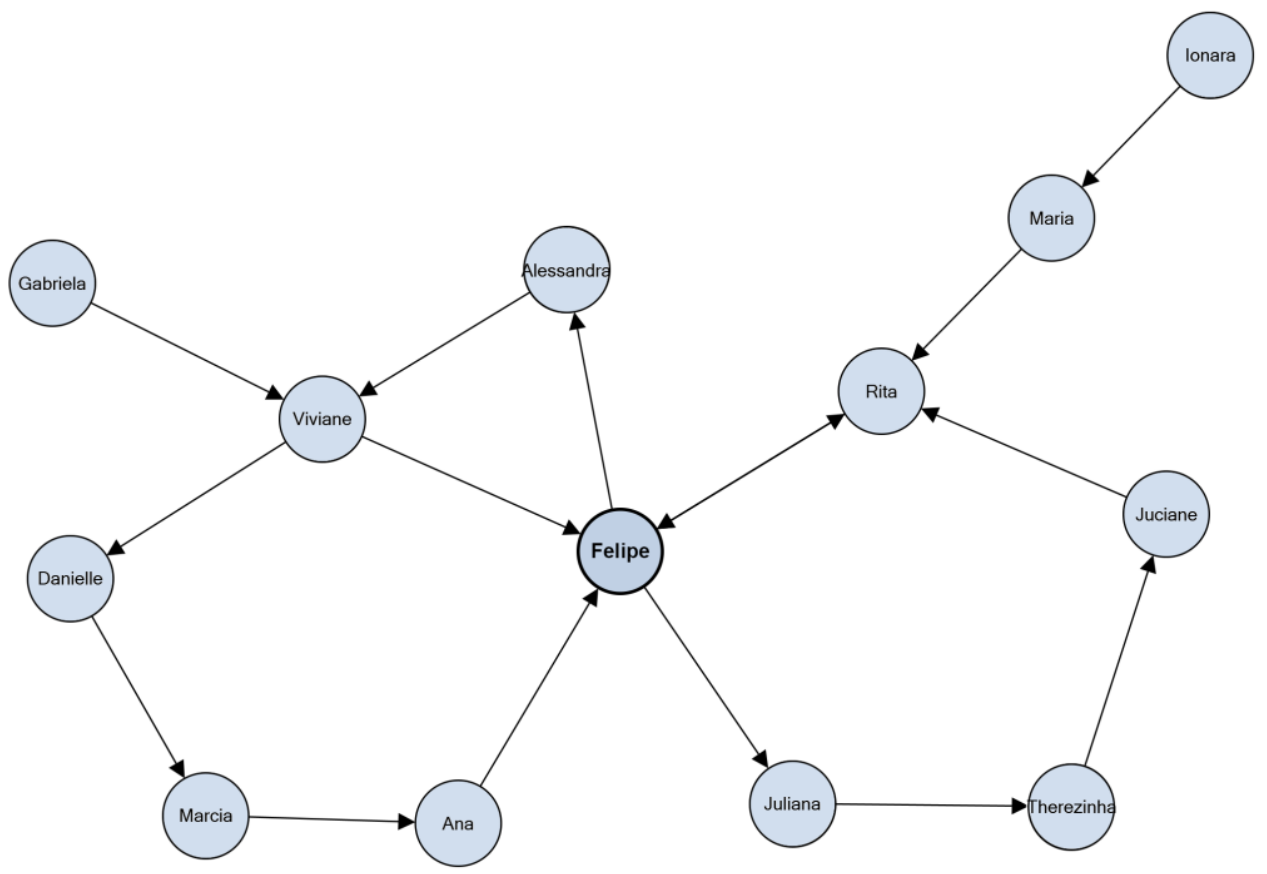

FIGURA 6 - Rede Social emergente da conversação do Texto 1 (sociograma)

A partir da inspeção visual da rede social representada na Figura 6, é possível notar que o tutor-pesquisador Felipe ocupou uma posição central nesta conversa, dado que esta configuração espacial se deve ao grau do vértice, que é a soma do grau de saída e do grau de entrada. Contudo, como já argumentado anteriormente, a atenção não foi centrada no tutorpesquisador Felipe, pois os alunos não ficaram dando respostas predominantemente para as 
mensagens do tutor, embora Felipe tenha produzido muitas mensagens para coordenar o grupo na construção colaborativa de conhecimento sobre a questão em discussão.

\section{CONCLUINDO COM OS ACHADOS DA PESQUISA}

Diante do que foi analisado na seção anterior, emergiu a noção subsunçora "mediação docente online para colaboração", que explica a ação de mediação do tutor-pesquisador nesta pesquisa-formação na cibercultura. Como princípios da mediação docente online para colaboração, identificamos:

- convidar todos os cursistas para participar da discussão;

- exercer uma mediação ativa, não se ausentar do fórum nem ficar só observando a conversação dos cursistas; intervir, quando necessário, para incentivar a construção colaborativa de conhecimento sobre a questão em discussão, mas tomando cuidado para não se tornar o centro da atenção da conversação;

- promover conversas autênticas, autorais, contextualizadas nas experiências dos cursistas, dialogando com as práticas cotidianas, incentivando-os a externalizarem suas próprias reflexões e partilharem experiências em grupo; evitar apresentação de perguntasconteudistas que exijam uma resposta desvinculada da realidade do aluno, cujas respostas podem até ser encontradas na internet, pois torna o fórum um espaço de pergunta-resposta com pouca discussão.

- incentivar a interatividade entre os próprios cursistas a partir de suas narrativas, promovendo o cruzamento de ideias entre as diferentes narrativas;

- promover o desdobramento da conversação, ora aprofundando o que está sendo discutido, ora ampliando o debate com outras fontes de informação, novos pontos de vista e variadas concepções de um mesmo assunto;

Estes são os princípios que identificamos para direcionar a prática da mediação docente que se volta para a promoção da colaboração em tempos de cibercultura. Compreendemos a mediação docente como um ato, uma ação ou uma prática mediadora entre a turma e o objeto de conhecimento a ser construído colaborativamente, sendo fundamental para o processo formativo dos aprendentes. A mediação deve buscar a interatividade docentediscentes e discentes-discentes requerendo uma postura participativa, com discussão que aprofunde e amplie o conteúdo proposto, que amplie a visão crítica, que articule a construção do conhecimento a partir do diálogo com todos. A discussão é o que nos possibilita compreender e reconhecer as pluralidades das relações que estabelecemos com o nosso cotidiano, com as problemáticas que delas emergem na medida em que respondemos as complexidades das nossas questões, que não estão perspectivadas de um modo padronizado de respostas, mas sim heterogêneas e plurais. "A sua pluralidade não é só em face dos diferentes desafios que partem do seu contexto, mas em face de um mesmo desafio" (FEIRE, 1967, p. 44). Para dar conta da pluralidade das relações existentes no mundo, em busca e no jogo de novas respostas, nas quais perguntas novas também emergem, o homem transcende. 
Nesta pesquisa-formação na cibercultura, identificamos que a mediação docente online necessita da prática de mediação voltada para a promoção da colaboração. Este texto é uma obra aberta e esperamos dos nossos leitores mais e melhores oportunidades de diálogo para que possamos continuar investindo em mais e melhores práticas de pesquisa e formação na cibercultura.

\section{REFERÊNCIAS}

ARDOINO, Jacques. Nota a propósito das relações entre a abordagem multirreferencial e a análise institucional (história ou histórias). In: BARBOSA, Joaquim G. (Org.).

Multirreferencialidade nas ciências e na educação. São Carlos: Editora da UFSCar, 1998. p. $42-49$.

BRUNO, Adriana Rocha. Mediação partilhada em redes sociais rizomáticas: (des)territorialização de possibilidades para a discussão sobre o ser tutor-pesquisador e a tutor-pesquisadoria em cursos online. In: FONTOURA, Helena; SILVA, Marco (Org.)

Práticas pedagógicas, linguagem e mídias: desafios à pós-graduação em Educação em suas múltiplas dimensões. Rio de Janeiro: ANPEd, 2011. p.116-131.

CASTRO, Alberto; MENEZES, Crediné. Aprendizagem colaborativa com suporte computacional. In: PIMENTEL, Mariano; FUKS, Hugo (Org.). Sistemas colaborativos. Rio de Janeiro: Elsevier, 2011. p.135-153.

CALVÃO, Leandro Dantas; PIMENTEL, Mariano; FUKS, Hugo. Do e-mail ao Facebook: uma perspectiva evolucionista sobre os meios de conversação da internet. Rio de Janeiro: Ed. UNIRIO, 2014.

CENSO EaD.br. Relatório analítico da aprendizagem a distância no Brasil. 2013. ABED - Associação Brasileira de Educação a Distância. Curitiba: Ibpex, 2014.

DIAGRAMA de caixa. Wikipédia. Disponível em: < https://goo.gl/NQUGMD>. Acesso em: 25 jul. 2015.

ELLIS, Clarence A., GIBBS, Simon J., REIN, Gail. Groupware: some issues and experiences. Communications of the ACM, v. 34, n. 01, p. 39-58. jan. 1991. Disponível em: < http://goo.gl/khe3dy>. Acesso em: 23 set. 2015.

FREIRE, Paulo. Educação como prática da liberdade. In: FREIRE, Paulo. Pedagogia da autonomia: saberes necessários para a prática educativa. São Paulo: Paz e Terra, 1996.

FUKS, Hugo; RAPOSO, Alberto Barbosa, GEROSA, Marco Aurélio, PIMENTEL, Mariano, FILIPPO, Denise, LUCENA, Carlos José Pereira. Teorias e modelos de colaboração. In: PIMENTEL, Mariano; FUKS, Hugo (Org.). Sistemas colaborativos. Rio de Janeiro: Elsevier, 2011. p.16-33. 
GEROSA, Marco Aurélio; PIMENTEL, Mariano; FUKS, Hugo; LUCENA, Carlos José Pereira. Coordenação de fóruns educacionais: encadeamento e categorização de mensagens. In: XIV Simpósio Brasileiro de Informática na Educação. Rio de Janeiro: SBC, 2003. p. 45-54. Disponível em: < http://goo.gl/OaSg3W>. Acesso em: 23 set. 2015.

GRAPHPAD QuickCalcs. Disponível em: < http://goo.gl/Nw71JD> Acesso em: 25 jul. 2015.

INEP. Censo da Educação Superior 2012. MEC, 2012. Disponível em:

<http://goo.gl/J8HqbA> . Acesso em: 20 nov. 2014.

MACEDO, Roberto Sidney. Compreender e mediar a formação: o fundante da educação. Brasília: Liber Livro Editora, 2010.

MEIRA, Silvio Romero Lemos, COSTA, Ricardo Araújo, JUCÁ, Paulyne, SILVA, Edeilson Milhomem. Redes sociais. In: PIMENTEL, Mariano; FUKS, Hugo. Sistemas colaborativos. Rio de Janeiro: Elsevier, 2011. p. 53-64.

NODEXL. In: Wikipédia. Disponível em: < https://goo.gl/lJ2wXH>. Acesso em: 25 jul. 2015.

OUTLIER Calculator. Disponível em: < http://goo.gl/kRtl6x > Acesso em: 25 jul. 2015.

PIMENTEL, Mariano. Interação não garante colaboração. Palestra proferida na Universo, Niterói, 2015. Disponível em: < http://goo.gl/xjmKAy> Acesso em: 25 jul. 2015.

RECUERO, Raquel. A conversação em rede: comunicação mediada pelo computador e redes sociais na internet. Porto Alegre: Sulina, 2012.

RECUERO, Raquel; ZAGO, Gabriela; BASTOS, Marco Toledo. Análise de redes para mídia social. Porto Alegre: Sulina, 2015.

SANTOS, Edméa Oliveira. Educação online: cibercultura e pesquisa-formação na prática docente. 351 f. 2005. Tese (Doutorado em Educação) - Faculdade de Educação, Universidade Federal da Bahia, Salvador, BA, 2005. Disponível em: < https://goo.gl/117Vln>. Acesso em: 23 set. 2015.

SANTOS, Edméa Oliveira. Pesquisando com a mobilidade ubíqua em redes sociais da internet: um case com o Twitter. ComCiência, Campinas, SP, 2012. Disponível em $<$ http://goo.gl/xTlX9P $>$. Acesso em: 31 jul. 2015. ISSN 1519-7654.

SANTOS, Edméa Oliveira. Pesquisa-formação na cibercultura. Santo Tirso: Whitebooks, 2014.

SILVA, Marco. Formação de professores para a docência online. Braga: Universidade do Minho, 2009.

SILVA, Marco; SANTOS, Edméa Oliveira. Conteúdos de aprendizagem na educação online: inspirar-se no hipertexto. Educação \& Linguagem, São Paulo, SP, v. 12, n. 19, p. 124142. jan./jun. 2009. Disponível em: 〈https://goo.gl/Bo3HkU〉. Acesso em: 23 set. 2015. ISSN: 2176-1043.

\begin{tabular}{l|l|l|l|l|l|l} 
(C) ETD -Educ. Temat. Digit. & Campinas, SP & v.18 & n.2 & p. 23-42 & jan.abr.2016 & ISSN $1676-2592$
\end{tabular}


SILVA, Valleska; PIMENTEL, Mariano; DIAS, Vânia Félix. Bate-papo colaborativo ou centrado no professor? In: 26. Simpósio Brasileiro de Informática na Educação. Salvador, BA, SBC, 2015. Disponível em: < http://goo.gl/MkSRKl>. Acesso em: 23 set. 2015.

WASSERMAN, Stanley; FAUST, Katherine. Social network analysis: methods and applications. England: Cambridge University Press, [s.d].

\section{Como citar este documento:}

SANTOS, Edméa Oliveira; CARVALHO, Felipe Silva Ponte; PIMENTEL, Mariano. Mediação docente online para colaboração: notas de uma pesquisa-formação na cibercultura. ETD - Educação Temática Digital, Campinas, SP, v. 18, n. 1, p. 23-42, abr. 2016. ISSN 1676-2592. Disponível em:

<http://periodicos.sbu.unicamp.br/ojs/index.php/etd/article/view/8640749>. Acesso em: 07 abr. 2016. doi: 〈http://dx.doi.org/10.20396/etd.v18i1.8640749>. 